\title{
БІОТЕХНОЛОГІЯ ТА БІОБЕЗПЕКА
}

Л.В. Король,

С.О. Гончарова,

О.В. Піскова,

А.В. Костенко,

I.I. Коровко

Український інститут експертизи сортів рослин

Л.М. Кожемякіна

Інститут біоенергетичних культур і цукрових буряків НАAН

\section{Ocобливості bиявлення}

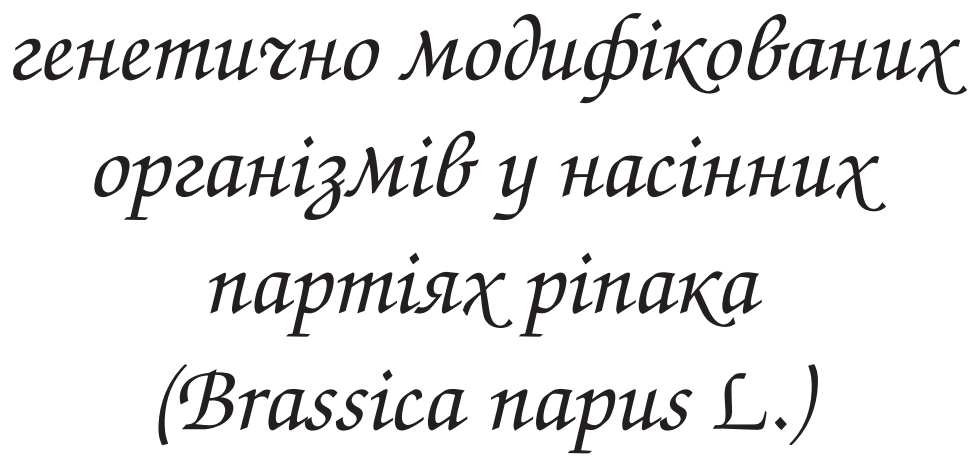

Наведено результати молекулярно-біологічних досліджень з апробації та оцінки мультиплексних тест-систем для ідентифікації генетично модифікованих організмів (ГМО) за допомогою полімеразної ланцюгової реакції (ПЛР) у реальному часі. Для виявлення генетичних модифікацій у рослинахродини хрестоцвітих (Brassicaceaе) недостатнімє скринінг основних регуляторних послідовностей, оскільки в генно-інженерних маніпуляціях використовується 35 промотор ДНК-умісного вірусу мозаӥки цвітної капусти (СаMV), наявність якого в досліджуваному матеріалі може призвести до отримання хибно позитивних результатів. Досліджено дочільність тесту на наявність ДНК-вірусу СаМV та аналізу скринінгових послідовностей генів інтересу для їхнього використання під час аналізу досліджуваних зразків насіння ріпака (Brassica napus L.).

Встановлено, що аналіз наявності / відсутності СаMV за позитивного результату по $35 \mathrm{~S}$ промотору не дає вичерпної відповіді стосовно відсутності ГМО у досліджуваному зразку. Обгрунтовано доцільність скринінгу ГМО у насінному матеріалі ріпака проводити за NOS термінатором і генами інтересу.

\section{Ключові слова:}

ріпак, ГМО, скринінгові послідовності ГМО, ПЛР у реальному часі, вірус мозаїки цвітної капусти (СаМV).

Вступ. В умовах значного поширення біотехнологічних культур необхідним $\epsilon$ контроль наявності генетично модифікованих організмів (ГМО) серед насінного матеріалу, оскільки виникає ризик забруднення посівів сільськогосподарських культур, отриманих з використанням як класичних методів селекції, так і генної інженерії [1]. Зокрема це стосується перехреснозапильних культур таких, як кукурудза та ріпак.

Ріпак $\epsilon$ основною олійною культурою у багатьох країнах світу, яка на сьогодні посідає третє місце після сої культурної та бавовнику і друге за валовим виробництвом олії. Селекція ріпака ведеться за двома основними напрямами: зниження вмісту глюкозинолатів, оптимізація співвідношення жирних кислот і підвищення вмісту ерукової або лауринової кислот [2]. 3 розвитком технологій генної інженерії були створені сорти ріпака, що характеризуються стійкістю проти гербіцидів широкого спектра дії, шкідників та пониженої температури, мають модифікований жирнокислотний склад олії, здатність до продукування фармакологічних білків та си- ровини для виробництва біодеградуючих полімерів, а також несуть ознаку чоловічої стерильності. Зі створенням таких культур виникла необхідність у розробці методів для їхнього скринінгу.

Загальноприйнята схема виявлення й ідентифікації ГМО включає наступні етапи: 1) первинний скринінг насінного матеріалу, 2) аналіз наявності зареєстрованих ГМО, 3) кількісне визначення ГМО. Як скринінгові послідовності ГМО зазвичай використовують 35S промотор та NOS термінатор Agrobacterium tumefaciens, 
Особливості виявлення генетично модифікованих організмів у насіннєвих партіях ріпака (Brassica napus L.)

оскільки вони входять до складу більш ніж 80\% ГМО [3, 4]. Однак скринінг за $35 \mathrm{~S}$ промотором не підходить для ріпака, оскільки цей промотор взято з ДНК-умісного вірусу мозаїки цвітної капусти (Cauliflower mosaic virus - CaMV), який має здатність уражувати представників родини хрестоцвітих. Отже, під час проведення досліджень на вміст ГМО у зразках ріпака надзвичайно великий ризик отримання хибних позитивних результатів. Мінімізувати ризик можна двома шляхами: або не використовувати у тесті 35 промотор CaMV, або для позитивних за цим промотором зразків використовувати додатковий тест на наявність ДНК-вірусу CaMV.

Метою нашої роботи було дослідити доцільність тесту на наявність ДНК-вірусу CaMV та проаналізувати інші послідовності для використання їх як скринінгові, під час аналізу насінних зразків ріпака.

Методи досліджень. В Україні затверджено ряд нормативних документів і методик, що забезпечують проведення досліджень 3 виявлення та ідентифікації ГМО. Зокрема розроблено державні стандарти України для етапів відбору проб, виділення ДНК, скринінгу ГМО $[5,6,7,8]$. За ідентифікації ГМО у рослинному матеріалі виділяють наступні етапи:

- виділення ДНК з досліджуваного зразка;

- скринінг на наявність ГМО;

- перевірка позитивних за $35 \mathrm{~S}$ промотором і NOS термінатором зразків на наявність CaMV i A. tumefaciens;

- ідентифікація ГМО.

Виділення ДНК. Першим етапом аналізу на наявність ГМО у рослинному матеріалі 3 допомогою ПЛР $\epsilon$ виді- лення ДНК. Для отримання високоочищеної нуклеїнової кислоти, що не містить інгібуючих домішок, необхідно використовувати найоптимальніші методи [1]. Для виділення ДНК $з$ насіння ріпака відбирали 1000 насінин й розмелювали на муку. Для подальших маніпуляцій використовували по 100 мг зразка. Виділення ДНК проводили 3 використанням катіонного детергенту бромід цетилтриметиламонію (cetyltrimethylammonium bromide, ЦТАБ) із сорбентом $[6,8]$. Для отриманих зразків ДНК визначали концентрацію та ступінь очистки на спектрофотометрі, використовуючи TE-буфер для калібрування.

Скринінг генетично модифікованих організмів. 3 метою виявлення ГМО у зразках ріпака використовується три мультиплексні тест-системи.

Перша містила праймери та флуоресцентні зонди для виявлення специфічного гена рослин, 35S промотору та NOS термінатора («Растение / 35S / NOS скрининг», Синтол, Російська Федерація). Дана тест-система призначена для виявлення ГМО рослинного походження у продуктах харчування, сировині та кормах для тварин методом ПЛР у реальному часі та рекомендована для використання при аналізі будь-яких зразків, зокрема і багатокомпонентних, дає змогу встановити наявність можливих ліній ГМО без їх ідентифікації.

Друга тест-система містила праймери та флуоресцентні зонди для виявлення специфічного гена рослин та CaMV («АмплісенсСенс ${ }^{\circledR}$ CamV-FL», АмплісенсСенс ${ }^{\circ}$, Російська Федерація). Набір реагентів, призначений для виявлення ДНК
CaMV у продуктах харчування і кормах, методом ПЛР 3 гібридизаційно-флуоресцентною детекцією. Використання даного тестового набору сприяє отриманню інформації про походження ДНК $35 \mathrm{~S}$ промотору, що наявний у зразку, який може бути як вірусним, так і трансгенним.

Тест-система «ГМО рапс скрининг» (Синтол, Російська Федерація) містить праймери до структурного гена ріпака CruA, NOS термінатора, генів фосфінотріцин $\mathrm{N}$-ацетилтрансферази із Streptomyces viridochromogenes (Pat) та 5-енолпірувілшикімат3-фосфат синтетази (сp4 EPSPs), використовується для ідентифікації генетичних модифікацій ріпака шляхом визначення характерних послідовностей ДНК-методом ПЛР у реальному часі й рекомендована виробником для аналізу рослин або насіння ріпака. Аналіз визначає більшість 3 комерційно зареєстрованих ліній ріпака без їхньої детальної ідентифікації.

Перша та друга тест-системи передбачають використання внутрішнього контролю реакції, що дає можливість виявити присутність речовин, які інгібують реакцію для третьої тест-системи, контроль можна здійснити за специфічним геном рослин. ПЛР проводили згідно 3 інструкцією виробників в ампліфікаторі $i^{T M} 5$ Optical Module (Bio-Rad, США), включаючи негативний контроль виділення ДНК з наступними параметрами (табл.).

Результати досліджень. У процесі роботи проаналізовано кожен етап ідентифікації ГМО в насінному матеріалі. Для отриманих препаратів ДНК з використанням ЦТАБ-методу 
Особливості виявлення генетично модифікованих організмів у насіннєвих партіях ріпака (Brassica napus L.)

Параметри ампліфікації зразків ріпака

\begin{tabular}{|c|c|c|c|c|}
\hline Назва тест-системи & $\begin{array}{c}\text { Початкова } \\
\text { денатурація }\end{array}$ & Денатурація & $\begin{array}{c}\text { Гібридизація } \\
\text { праймерів } \\
\text { та детекція } \\
\text { продуктів } \\
\text { реакції }\end{array}$ & $\begin{array}{c}\text { Кількість } \\
\text { циклів }\end{array}$ \\
\hline $\begin{array}{l}\text { «Растение / 35S / NOS } \\
\text { скрининг» }\end{array}$ & $95^{\circ} \mathrm{C}, 5 \times$ хв. & $95^{\circ} \mathrm{C}, 15 \mathrm{C}$ & $59^{\circ} \mathrm{C}, 40 \mathrm{C}$ & 45 \\
\hline $\begin{array}{l}\text { «АмплісенсСенс }{ }^{\circ} \\
\text { CamV-FL» }\end{array}$ & $95^{\circ} \mathrm{C}, 15 \times$ & $95^{\circ} \mathrm{C}, 15 \mathrm{C}$ & $59^{\circ} \mathrm{C}, 60 \mathrm{C}$ & 42 \\
\hline «ГМ рапс скрининг» & $95^{\circ} \mathrm{C}, 5 \times$ хв. & $95^{\circ} \mathrm{C}, 15 \mathrm{C}$ & $61^{\circ} \mathrm{C}, 40 \mathrm{C}$ & 45 \\
\hline
\end{tabular}

і сорбенту визначали ступінь очистки та концентрацію на спектрофотометрі, використовуючи ТЕ-буфер з метою калібрування. Концентрація ДНК, виділеної зі зразків насіння ріпака, знаходилась у межах 150-270 мг/мл, при цьому співвідношення А260/А280 було $1,7-1,8$.

Реакцію ампліфікації здійснювали з використанням трьох різних комерційних наборів 3 метою виявлення ГМО у зразках ріпака та оцінки можливих ризиків за отримання хибно позитивних результатів.

Результатом ПЛР-аналізу у реальному часі $\epsilon$ графік флюоресценції досліджуваних зразків і цифрові дані порівняння графіків накопичення ДНК. У результаті проведених досліджень виявлено, що для зразків насіння ріпака характерна наявність сигналу за флуоресцентною пробою $35 \mathrm{~S}$ промотору. Стосовно до схеми проведення аналізів на вміст ГМО в рослинному матеріалі, наступним кроком $\epsilon$ аналіз на наявність CaMV, причому за умови виявлення ДНК CaMV досліджувані зразки розцінюються як негативні. Однак, на наш погляд, така схема аналізу не $\epsilon$ достатньою, оскільки результати якісного аналізу будуть однаковими для зразків, що містять лише CaMV, i для зразків, що містять гене- тично модифіковані організми і CaMV. Так було досліджено зразки ріпака, що мали позитивний сигнал лише по $35 \mathrm{~S}$ промотору на вміст CaMV (рис. 1). Зразки, для яких не виявлено позитивного сигналу по CaMV, розцінювались як такі, що містять ГМО та в подальших дослідженнях не ви-

У тест-системі, з використанням якої отримані дані результати, барвником JOE промарковано зонд до структурного гена ріпака, а барвником $R O X-$ зонд до послідовності CaMV.

Аналіз позитивних за CaMV зразків на наявність гена енолпірувілшикіматфосфатсинтетази (EPSPS) та фосфінотріцин $\mathrm{N}$-ацетилтрансферази (Pat) показав присутність у частини зразків послідовностей EPSPsгена (рис. 3). Значення порогового циклу реакції (threshold cycle $-(t)$ для трьох зразків рікористовувались. пака за барвниками FAM (карбоксифлуоресцеїн), HEX (6-карбоксиродамін), ROX, Cy5 наведено на рис. 2.

На рис. 2. відображено процес накопичення цільових фрагментів структурного гена ріпака CruA, NOS термінатора, Pat гена та EPSPs гена, а також порогові лінії для флуоресцентних барвників, відповідно яким встановлено значення $C_{t}$.

Отримані дані свідчать про присутність послідовностей ДHК NOS термінатора у зразках №443 і №444 (порогові цикли за барвником FAM - 27 та 33) та EPSPs гена у цих же зразках (пороговий цикл за барвником Су5 - 38). За барвником HEX, що вказує на наявність структурного гена ріпака CruA, отримано позитивний результат по всіх зразках.

Висновки. 1. Скринінг насінного матеріалу рослин, що відносяться до родини хрестоцвітих (Brassicaceae) доцільно проводити за NOS термінатором та генами інтересу. Аналіз наявності/відсутності CaMV не дає вичерпної відповіді стосовно до відсутності ГМО у зразку.

2. У подальшій роботі для аналізу зразків насіння родини хрестоцвітих (Brassicaceae) на вміст ГМО слід рекоменду-

\begin{tabular}{|c|c|c|c|c|c|c|}
\hline Well & Fluor & Type & Identifier & Replicate \# & $\begin{array}{l}\text { Threshold Cycle } \\
\text { (Ct) }\end{array}$ & Ct Std. Dev \\
\hline 804 & JOE & Unkn & N274pinak (35S+) & 2 & 14,40 & $14,40 \mathrm{~N} / \mathrm{A}$ \\
\hline$B 06$ & JOE & Unkn & N975pinak (35S+) & 3 & 17,10 & $17,10 \mathrm{~N} / \mathrm{A}$ \\
\hline$B 08$ & JOE & Unkn & N276pinak (35S+) & 4 & 14,10 & $14,10 \mathrm{~N} / \mathrm{A}$ \\
\hline B11 & JOE & $\mathrm{Neg} \mathrm{Ctrl}$ & OK & \multicolumn{2}{|c|}{$1 \mathrm{~N} / \mathrm{A}$} & $00,00 \mathrm{~N} / \mathrm{A}$ \\
\hline $\mathrm{D} 02$ & JOE & Unkn & №79 pinak (35S+) & 5 & 14,05 & $14,05 \mathrm{~N} / \mathrm{A}$ \\
\hline $\mathrm{D} 04$ & JOE & Unkn & No80pinaк (35S+) & 6 & 15,17 & $15,17 \mathrm{~N} / \mathrm{A}$ \\
\hline G11 & JOE & Pos Ctrl & $\mathrm{nK}+$ & 1 & 27,26 & $27,26 \mathrm{~N} / \mathrm{A}$ \\
\hline$B 04$ & BOV & Unkn & №74pinak (35S+) & 2 & 25,86 & $25,00+1 / 4 / 4$ \\
\hline & ROX & Unkn & N275pinak (35S+) & 3 & 31,31 & $31,31 \mathrm{~N} / \mathrm{A}$ \\
\hline 808 & nox & Unkn & N976pinak (35S+) & 4 & 28,23 & $28.23 \cdot \mathrm{N} / \mathrm{A} / \mathrm{N}$ \\
\hline$B 11$ & ROX & $\mathrm{Neg} \mathrm{Ctrl}$ & $\mathrm{OK}$ & \multicolumn{2}{|c|}{$1 \mathrm{~N} / \mathrm{A}$} & $00,00 \mathrm{~N} / \mathrm{A}$ \\
\hline $\mathrm{DO2}$ & $\operatorname{Rex}$ & Unkn & №79 pinak (35S+) & 5 & 28,44 & $28,447 \mathrm{~V} / \mathrm{N} / \mathrm{M}$ \\
\hline & nov & Unkn & No80pinak (35S+) & 6 & 27,98 & $2708 \mathrm{~N} / \mathrm{A} / \mathrm{A}$ \\
\hline G11 & ROX & Pos Ctrl & $\Pi \mathrm{n}+$ & 1 & 28,70 & 28,70 N/A \\
\hline
\end{tabular}

Рис. 1. Результати перевірки п'яти зразків ріпака на наявність СaMV. 
Особливості виявлення генетично модифікованих організмів у насіннєвих партіях ріпака (Brassica napus L.)

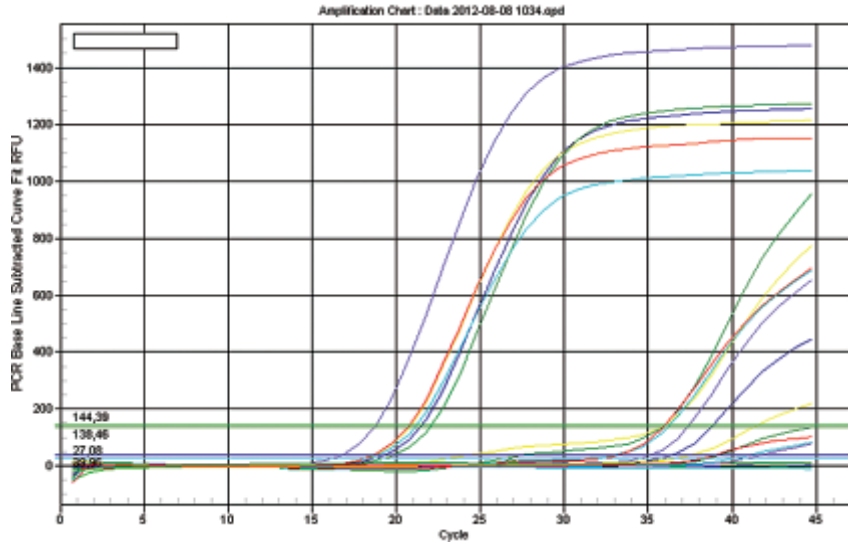

Рис. 2. Графік накопичення ДНК для зразків ріпака

\begin{tabular}{|c|c|c|c|c|c|c|c|c|}
\hline Well & Fluor & Trpe & Identffer & Replicate $=$ & $\begin{array}{l}\text { Threshold Cyde } \\
(\mathrm{Ct})\end{array}$ & CtMean & Ctstd. Dev & Set Point \\
\hline 802 & FAM & NTC & OKB & & $1 \mathrm{~N} / \mathrm{A}$ & $00,00 \mathrm{~N} / \mathrm{t}$ & & N/A \\
\hline 805 & FAM & Neg $\mathrm{Ctr}$ & o & & $\mathrm{N} / \mathrm{A}$ & $00,00 \mathrm{~N} / \mathrm{t}$ & & N/A \\
\hline 800 & FaM & Pos $\mathrm{COH}$ & $\pi \times$ & 1 & 27,93 & 28,05 & & $0 \mathrm{~N} / \mathrm{A}$ \\
\hline 002 & FAM & Uniten & pinax 442 & & N/A & 35,85 & & $5 \mathrm{~N} / \mathrm{A}$ \\
\hline 006 & Eaven & जाल & Dinas 443 & $\overline{2}$ & 27,76 & 26,13 & & $2+4 / 4$ \\
\hline 003 & fram & Unin & phax 444 & 3 & 33,18 & 33,24 & 2,08 & suth \\
\hline 802 & HEx & NTC & ЖKB & & $N / A$ & $00,00 \mathrm{~N} / \mathrm{t}$ & & $N / A$ \\
\hline 805 & Hex & $\mathrm{Neg} \mathrm{Crl}$ & \% & & $N / A$ & $00,00 \mathrm{~N} / \mathrm{t}$ & & N/A \\
\hline 808 & tex & Pos COI & $\mathrm{nK}$ & 1 & 33,32 & 33,62 & & $5 \mathrm{~N} / \mathrm{A}$ \\
\hline D02 & Hex & Unien & pinas 442 & 1 & 21,04 & 19,68 & & $8 \mathrm{~N} / \mathrm{A}$ \\
\hline 006 & Hex & Union & phax 443 & 2 & 21,64 & 21,02 & & $3 \mathrm{~N} / \mathrm{A}$ \\
\hline D08 & Hex & Union & pinas 444 & 3 & 20,76 & 20,54 & & $3 \mathrm{~N} / \mathrm{A}$ \\
\hline 802 & ROX & NTTC & OKB & & N/A & $00,00 \mathrm{~N} / \mathrm{t}$ & & $\mathrm{N} / \mathrm{A}$ \\
\hline 806 & ROX & $\mathrm{Neg} \mathrm{Ctrl}$ & \% & & $N / A$ & $00,00 \mathrm{~N} / \mathrm{t}$ & & N/A \\
\hline 808 & ROX & Pos COM & $\pi \mathrm{K}$ & 1 & 28,69 & 28,93 & & $6 \mathrm{~N} / \mathrm{A}$ \\
\hline 003 & ROX & Unken & pinas 442 & & N/A & $00,00 \mathrm{~N} / \mathrm{t}$ & & $N / A$ \\
\hline Do5 & ROX & Unim & pinas 443 & & N/A & $00,00 \mathrm{~N} / \mathrm{t}$ & & N/A \\
\hline 009 & ROX & Unikn & pinax 444 & & N/A & $00,00 \mathrm{~N} / \mathrm{t}$ & & N/A \\
\hline 802 & C>5 & |NTTC & ОКВ & & N/A & $00,00 \mathrm{~N} / \mathrm{I}$ & & N/A \\
\hline 806 & Cy5 & Neg Ctrl & \% & & N/A & $00,00 \mathrm{~N} / \mathrm{t}$ & & N/A \\
\hline 808 & Cys & Pos COT & $\mathrm{nK}$ & 1 & 27,36 & 27,64 & & $7 \mathrm{~N} / \mathrm{A}$ \\
\hline 002 & Cy5 & Unin & ghas 442 & & N/A & $00,00 \mathrm{~N} / \mathrm{L}$ & & $\mathrm{N} / \mathrm{A}$ \\
\hline & $6 \times 3$ & Unim & pinax 443 & 2 & 38,37 & 37,45 & & $376 / 2=$ \\
\hline DO9 & 5 & Inim & pinsox 444 & 3 & 38,02 & 38,99 & 1,23 & 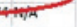 \\
\hline
\end{tabular}

Рис. 3. Результати скринінгу трьох зразків ріпака на наявність ГМО*

* Примітка: червоним кольором позначено позиції, що свідчать про наявність цільових послідовностей генетично модифікованих організмів. вати дві мультиплексні тестсистеми для проведення ПЛР у реальному часі. Одна з яких має включати праймери та флуоресцентні зонди для виявлення специфічного гена рослин, 355 промотору та NOS термінатора. При наявності позитивного сигналу на $35 \mathrm{~S}$ промотор необхідно продо- вжити аналіз даних зразків на виявлення генів інтересу, що забезпечують стійкість рослин до найбільш розповсюджених гербіцидів широкого спектра дії. Це завдання вирішується шляхом використання тестсистеми, що включає праймери та флуоресцентні зонди для виявлення структурного гена ріпака CruA, NOS термінатора, Pat гена та EPSPs гена. Запропонована схема проведення досліджень дає змогу швидко й 3 невеликими витратами отримати достовірні дані скринінгу ГМО ріпака, що містить вказані гени, та виключити можливість отримання хибно позитивних результатів.

\section{ВИКОРИСТАНА ЛІТЕРАТУРА}

1. Сорочинський Б.В. Генетично модифіковані рослини / Б.В.Сорочинський, О.О. Данильченко, Г.В. Кріпка. - К.: Фітосоціоцентр, 2005. - 204 с.

2. Ситнік І.Д. Озимий та ярий ріпак / І.Д. Ситнік, О.Л. Кляченко, О.Г. Какорін. - К.: Знання України, 2005. - 115 c.

3. Блюм Я.Б. Впровадження методів оцінки наявності та вмісту генетично модифікованих компонентів у продуктах харчування, кормах і парфумерно-косметичних виробах / Я.Б. Блюм, М.О. Банникова, П.А. Карпов [та інші] // Наука та інновації. - 2008. - T. 4, № 2. - С. 40-48.

4. Епринцев А.П. Идентификация и исследование экспрессии генов / А.П. Епринцев, В.Н. Попов, Д.Н. Федорин. - Воронеж, 2008. - 64 с.

5. ДСТУ ISO 21569:2008. Продукти харчові. Методи виявлення генетично модифікованих організмів і продуктів з їхнім умістом. Якісні методи на основі аналізування нуклеїнової кислоти (ISO 21569:2005, IDT): - Чинний від
2010-01-01 - К.: Держспоживстандарт України, 2009. - 50 c.

6. ДСТУ-П SEN/TS 15568:2008. Продукти харчові. Методи виявлення генетично модифікованих організмів і продуктів з їхнім вмістом. Відбирання проб (SEN/TS 15568:2006, IDT) - Чинний від 201001-01 - К. : Держспоживстандарт України, 2009. $10 \mathrm{c}$.

7. ДСТУ ISO 21570:2008. Продукти харчові. Методи виявлення генетично модифікованих організмів і продуктів з їхнім вмістом. Кількісні методи на основі аналізування нуклеїнової кислоти (ISO 21570:2005, IDT) - Чинний від 2009-07-01 - К.: Держспоживстандарт України, 2009. -83 с.

8. ДСТУ ISO 21571:2008. Продукти харчові. Методи виявлення генетично модифікованих організмів і продуктів 3 їхнім вмістом. Екстрагування нуклеїнової кислоти (ISO 21571:2005, IDT) - Чинний від 2009-07-01 - К.: Держспоживстандарт України, 2009. - 83 с. 